CASA, Vol.9 n.1, julho de 2011

c

Cadernos de Semiótica Aplicada

Vol. 9.n.1, julho de 2011

Publicação SEMESTRAL

ISSN: $1679-3404$

\title{
LÍNGUA, LITERATURA, ENUNCIAÇÃO E AFETIVIDADE: UMA ANÁLISE DA NARRATIVA CAMPO GERAL, DE GUIMARÃES ROSA
}

\section{LANGUAGE, LITERATURE, ENUNCIATION AND AFFECTIVITY:} AN ANALYSIS OF GUIMARÃES ROSA'S CAMPO GERAL.

Eliane Soares de Lima

USP- Universidade de São Paulo

FAPESP

\begin{abstract}
RESUMO: Sabendo da plena consciência de Guimarães Rosa de que um autor deve explorar a originalidade da expressão linguística, fazendo com que ela seja capaz de exercer seu poder para atuar sobre os homens, este artigo tem o intuito de, através da descrição dos procedimentos enunciativos adotados pelo autor mineiro em sua narrativa Campo Geral, demonstrar como a língua se firma, em seu texto, não conforme um espelho da realidade, tampouco como um instrumento de representação dos fatos, mas como forma de ação sobre o próprio homem. A ideia é identificar as estratégias adotadas pelo enunciador para a configuração da afetividade que envolve esse discurso. Para isso, a análise de três dimensões da narrativa serão privilegiadas: a tensiva, a discursiva e a textual.
\end{abstract}

PALAVRAS-CHAVE: enunciação; tensividade; discursivização; textualização; afetividade.

ABSTRACT: Once aware of Guimarães Rosa's plain conscience about how an author must explore the originality of the linguistic expression, by making it able to practise its power of acting on men, this paper has the intention of demonstrating how the language settles, through the description of the enunciative proceedings adopted by the author in his narrative Campo Geral, not as a mirror of the reality or as an instrument of representation of the facts, but as a form of action on the man himself. The idea is to identify the strategies adopted by the enunciator for the configuration of the affectivity that involves this discourse. In order to do so, the analysis of three dimensions of the narrative will be privileged: the tensive, the discursive and the textual ones.

KEYWORDS: enunciation; tensive; discursivization; textualization; affectivity.

\section{Introdução}

Na literatura, o enunciador se mostra de modo peculiar em seu enunciado, ou seja, na ordem da ruptura. A presença é maximizada e tão mais impactante quanto mais se confundem os limites para o mundo percebido. Como aponta Discini (2009, p. 613), o enunciador literário esforça-se para "que o sujeito seja transportado de seu agir cotidiano e "se projete na estranha esfera do subir', ou da explosão do sentir". Desse modo, inteiramente encarnados no trabalho com a linguagem, substância e forma, nos textos literários, 
interpenetram-se na composição axiológica da realidade discursiva, que se faz viva e capaz de suscitar paixões.

A forma, seja a do conteúdo, responsável pelo seu modo de organização, ou a da expressão, ligada às diferentes maneiras de combinar os traços na manifestação, relativiza totalmente o discurso. Daí a singularidade do tratamento de temas universais, colocando em cena grandes autores, grandes estilos, que se destacam não pelo que dizem, mas essencialmente pelo modo como dizem, pelo jeito próprio como articulam o material linguístico na produção de seus textos.

No caso do discurso rosiano, a busca de ressignificação do conteúdo discursivo no plano da expressão é uma das suas características marcantes. Rosa inventa para sugerir e, na passagem do plano de conteúdo ao plano de expressão, reinventa o sentido na materialidade textual para sugerir mundos e sentimentos. Seus discursos, fundados em uma enunciação poética, acabam tendo um "sentido-além". À superfície textual subjaz um sentido outro, mais denso e abstrato, que atinge o leitor, intriga-o, levando-o à reflexão sobre a vida, sobre a morte, sobre o destino humano enfim.

De acordo com Coutinho (1994), o autor mineiro tinha plena consciência da missão do escritor de explorar a originalidade da expressão linguística, fazendo com que ela fosse capaz de recuperar seu poder e tornar-se apta a atuar sobre os homens. Segundo esse literato, Rosa deixa crer que a revolução na literatura deveria partir de dentro, da própria expressão literária, para poder atingir o leitor de maneira mais plena.

Nesse sentido, o enunciador rosiano avança na aparência das coisas. Cada palavra escolhida, cada forma de articulá-la dentro do discurso conferem existência concreta a um sentido que estava até então em estado potencial, fazendo com que à história contada sobreponha-se uma temática segunda. A "experimentação" dos acontecimentos e do próprio tempo parece valer mais do que as ações e o tempo em si, e é nesse ponto que se pode pensar na tensividade das percepções e na configuração do núcleo passional da narrativa, tais quais depreendidos no exame não só do narrado, mas também, e essencialmente, da forma de narrar. A subjetividade e a profundidade das personagens, construídas e apreendidas no e pelo discurso, remetem a uma maneira própria de presença no mundo, do ethos e do pathos típicos ao discurso, que é a imagem que Rosa dá de si e de seu enunciatário, enquanto ficcionaliza a realidade.

Sendo assim, a intenção da análise acerca da afetividade configurada no enunciado Campo Geral que aqui propomos é a de investigar, através dos procedimentos enunciativos adotados por Rosa, como a língua se firma não conforme um espelho da realidade, tampouco como mero instrumento de representação dos fatos, mas como forma de ação sobre o próprio homem. Para isso, privilegiaremos o exame de três dimensões da narrativa: a tensiva, a discursiva e a textual.

\section{Enunciação e afetividade em Campo Geral: uma análise semiótica.}

\subsection{A configuração tensiva}

A abordagem tensiva propõe uma sintaxe que visa a dar conta dos movimentos e inflexões, isto é, das modulações que, diretamente associadas ao universo sensível, servem de base para a construção passional do discurso. Ela concede papel de destaque à enunciação e à afetividade, entendendo o enunciado como uma arena do movimento, um espaço contínuo e tensivo, que caracteriza a interlocução entre enunciador e enunciatário. Desse modo, o ponto 
de vista tensivo compreende a participação do sujeito enunciativo em toda a extensão do percurso gerativo do sentido, sendo a escolha e a articulação dos valores tensivos e fóricos, no nível profundo, a matriz das funções narrativas e das debreagens e embreagens que consolidarão os outros estratos no caminho à superfície do discurso. Nas palavras de Tatit (2001, p. 25):

Portador das categorias mais abstratas do sistema gerativo, o nível tensivo se faz presente em todos os demais estratos do percurso, quer pela confirmação das escolhas fundamentais nos planos de superfície, quer pela denegação dessas mesmas escolhas no decorrer das fases de conversão.

Nessa perspectiva, os estados juntivos de conjunção e disjunção do sujeito com seu objeto-valor agem como operações tensivas regidas pela implicação ou pela concessão, que, por sua vez, respondem pela dinâmica dos discursos, pelo seu ritmo. Concentrando-nos, por exemplo, na passagem de Campo Geral referente ao acidente de Dito, irmão de Miguilim, veremos que a alternância contínua entre os valores de infância e maturidade, vida e morte, cria um espaço tensivo complexo que, regido por inflexões de tonicidade e de andamento, responde pela realização do sentido latente do texto e garante a coerência da irrupção concessiva, no caso, a morte de Dito.

Entre as várias situações e aventuras vividas pela personagem central da narrativa, Miguilim, dedicaremos maior atenção, em nossa análise, a essa passagem. Tal escolha se justifica pelo fato de esse episódio concentrar, em maior grau, a carga tímica do discurso. Ao longo da narrativa, vamos percebendo a amizade e a cumplicidade que há entre os dois irmãos. Miguilim confia e admira o irmão, tendo-o como "a pessoa melhor", "levado de esperto" (ROSA, 1996, p. 25), aquele que "era menor mas sabia o sério, pensava ligeiro as coisas" (idem, p. 21). A morte de Dito é, portanto, um momento-chave na trajetória existencial de Miguilim, o pico de intensidade máxima de sua experiência sensível e, consequentemente, de toda a história.

Tudo ia bem entre os dois irmãos até que Dito, contrariando a superstição de Miguilim, resolve ir ver um ninho de corujas não muito longe dali. Na volta para casa, Dito, junto com os irmãos e amigos, entra na correria para capturar o mico-estrela que havia fugido. Na perseguição, ele pisa em um caco de pote, cortando profundamente o pé. Depois de alguns dias, quando parecia já se recuperar do ferimento, o menino é acometido por uma forte dor nas costas e na cabeça. A família toda se mobiliza na tentativa de aliviar o seu sofrimento. Miguilim, sempre muito apegado ao irmão, fica ao seu lado durante todo o tempo, tentando animá-lo e distraí-lo. Nesse período, o estado de Dito oscila entre melhoras e pioras, entre momentos de descontração com Miguilim e gritos e gemidos de dor, até o momento de sua morte.

A partir desse breve resumo, podemos perceber que a passagem do estado inicial ao acontecimento final, figurativizado pela morte de Dito, é configurada por categorias temporais aspectualizadas, definindo um devir engendrado na duração, na extensão do percurso passional. O devir, como explica Mancini (2005, p. 94), “assume o papel de mediação entre a dinâmica de fluxos do nível tensivo e o nível da realização discursiva, de modo a constantemente atualizar os recursos utilizados pelo sujeito da enunciação para aspectualizar o enunciado". Ele pode ser visto, portanto, como um modo particular de organização do campo tensivo, resultante da interação entre enunciador e enunciatário.

O processo que assinala a performance que leva à morte de Dito é marcado, então, por recrudescimentos e atenuações da intensidade que definem um estilo tensivo Disponível em: http://seer.fclar.unesp.br/casa 
instável, constituído de percursos de ascendência e de descendência da tensão, de oscilações tímicas, que ora acentuam a desaceleração que distende essa tensão, ora a rapidez que a contrai, como mostram os trechos que seguem:

O Dito não podia caminhar, só podia pulando num pé só, mas doía, porque o corte tinha apostemado muito, criando matéria. Chamando, o Gigão vinha, vigiava a rede, olhava, olhava, sacudia as orelhas. "- Você está danado, Dito, por causa?" “- Estou não, seo Luisaltino, costumei muito com essas coisas...” “- Depressa que sare!” “- Uê, p'ra se sarar basta se estar doente.” Meu-deus-do-céu, e o Dito já estava mesmo quase bom, só que tornou outra vez a endefluxar, e de repente ele mais adoeceu muito, começou a chorar estava sentindo dor nas costas e dor na cabeça tão forte, dizia que estavam enfiando um ferro na cabecinha dele. Tanto gemia e exclamava, enchia a casa de sofrimento. (ROSA, 1996, p. 101-102).

No outro dia, o Dito estava melhorado. Só que tinha soluço, queria beber água-com-açúcar. Miguilim ficava sentado no chão, perto dele. [...] Mas agora o Dito não podia ir ajudar a arrumação, e então Miguilim gostava de não ir também, ficar sentado no chão, perto da cama, mesmo quando o Dito tinha sono, o Dito agora queria dormir quase todo o tempo. (idem, p. 102/ 103).

O Dito tinha alegrias nos olhos; depois, dormia, rindo simples, parecia que tinha de dormir a vida inteira.

[...] A dor-de-cabeça do Dito tinha voltado forte, mas agora Luisaltino tinha trazido as pastilhazinhas, ele engolia, com gole d'água, melhorava. (idem, p. 104).

Então, de repente, o Dito estava pior, foi aquela confusão de todos, quem não rezava chorava, todo mundo queria ajudar. [...] O Dito às vezes estava zarolho, sentido gritava alto com a dor-de-cabeça, sempre explicavam que a febre dele era mais forte, depois ele falava coisas variando, vomitava, não podia padecer luz nenhuma, e ficava dormindo fundo, só no meio do dormir dava um grito repetido, feio, sem acordo de si. Miguilim desentendia de tudo, tonto, tonto. Ele chorou em todas partes da casa. (idem, p. 106/107).

O momento em que Dito corta o pé se coloca no discurso rosiano como uma primeira cesura, uma interrupção da continuidade do percurso narrativo do sujeito, desencadeando e concentrando a tensão, o que leva o enunciado, agora sob o impacto da concessão, ao percurso tensivo da ascendência e da aceleração, configurando os efeitos passionais típicos da surpresa. A melhora de Dito, por outro lado, reconfigurando a continuidade, atenua a intensidade, distendendo-a e marcando o percurso de descendência da tensão, de relaxamento e desaceleração, segundo a ordem da implicação. Ou seja, se o estado inicial é abalado pela irrupção do acontecimento inesperado, engendrando a surpresa que concentra a tensão e abala o sujeito, ele se restabelece novamente no momento seguinte, atenuando a tensão e permitindo ao sujeito relaxar, pelo menos até que, como mostram os exemplos acima, haja um novo recrudescimento, seguido de uma nova atenuação, e ainda outro recrudescimento e outra atenuação, até chegar, finalmente, ao acontecimento principal, e clímax da narrativa, a morte de Dito. 
Essa passagem referente ao ferimento fica marcada, então, no nível profundo, pela dualidade entre estado e acontecimento - dualidade típica à temporalidade fórica, segundo Zilberberg (2006) -, gerando uma tensão entre os valores temporais da continuidade e da descontinuidade que pode ser sentida, experimentada, pelos sujeitos - tanto do enunciado, as personagens, quanto da enunciação, o enunciatário - através de seus resultados, no plano narrativo, a espera e a surpresa, respectivamente.

Assim, a partir da extensão temporal da situação inicial à final, do estado ao acontecimento, o enunciador de Campo geral vai fazendo inflexões tônicas no conteúdo do enunciado, aguçando a percepção do enunciatário e fazendo com que o tempo se coloque mesmo como presença. A articulação entre os valores temporais de descontinuidade e de continuidade discursiva faz com que o percurso passional de Miguilim fique marcado por modulações e oscilações tímicas, às vezes eufóricas e às vezes disfóricas, e por um ritmo que perfaz o movimento de expansão e de concentração da intensidade, produzindo expectativas não só em Miguilim, mas também no enunciatário.

O acontecimento é precedido, na composição desse discurso, por um jogo de acentos de sentido, de pausas e de intervalos, que intensificam a espera, permitindo ao sujeito a possibilidade de um não crer na disjunção concessiva, enchendo-o de esperança, porque a duração é o tempo do não ainda. Só que se Miguilim agarra-se à esperança da não disjunção, apegando-se aos conteúdos de vida que configuram o processo em questão, o enunciatário vai sendo tomado, pouco a pouco, pelos conteúdos de morte disseminados, sensibilizando-se e compadecendo-se diante da possibilidade de irrupção do fato concessivo.

Penetrado pela "espera do inesperado", prevendo o sobrevir, o leitor pressupõe o tamanho do "estrago" que a morte fortuita de Dito causará em Miguilim, e isso lhe incita a ansiedade, o compartilhamento do sofrimento do garoto. A extensão temporal do enunciado se configura, portanto, como um estado de alternância tímica, estando, o seu desenrolar, intrinsecamente relacionado ao desenvolvimento das emoções no sujeito.

A morte de Dito, enquanto concretização factual do acontecimento, afigura-se como surpresa, como tempo do já que se impõe ao não ainda. Daí o impacto sobre o sujeito, o sofrimento exacerbado, que discursiviza o querer-não-crer de Miguilim, e o compadecimento do enunciatário. O enunciador de Campo Geral, explorando no nível profundo a tensão entre os mecanismos tensivos de contenção e distensão da tensão, de descontinuidade e continuidade do percurso narrativo, utiliza os efeitos de surpresa e espera para sensibilizar o enunciatário e garantir o elo (afetivo) que o liga a Miguilim. É esse "elo" que permite ao leitor vivenciar mesmo a história, a se angustiar, alegrar-se e sofrer junto com a personagem.

Além disso, o andamento e a tonicidade, regendo a intensidade do discurso de Campo Geral pela gradação de aumentos e diminuições, dirigem a duração do devir, que converte a transformação narrativa pontual em processo, marcando o percurso ascendente que leva do desdobramento à somação. As pioras de Dito se colocam, pois, como acentos de sentido na composição discursiva, na configuração temporal da narrativa, como inflexões de tonicidade que concentram a tensão, para depois a distender, criando para o texto um estilo tensivo instável.

O ritmo imputado ao discurso rosiano acaba, nesse sentido, por funcionar como uma unidade de medida da afetividade, como uma instância de conversão e de sincronização das diferentes ordens sensoriais. Os sentidos e o corpo todo são sensibilizados pelos efeitos de sentido e engajados a agir na apreensão. Sensorial, sensível e inteligível atuam em sinergia para garantir o fazer persuasivo, inerente ao ato de enunciar. 


\subsection{Os procedimentos de discursivização.}

A discursivização responde pela representação semântico-sintáxica do texto, a qual tem por efeito a trama discursiva, a maneira específica pela qual o enunciatário toma conhecimento do narrado. Diretamente ligado à instância do discurso, é o sujeito da enunciação quem controla e manipula as vias de acesso a sua significação e aos valores que estão em sua base. É através dele que os esquemas narrativos, os formantes sintáxicos e passionais convertem-se em discurso pela projeção de uma "voz" enunciante.

Se, por um lado, a sintaxe intensiva do discurso é capaz de sensibilizar a manifestação discursiva, levando o enunciatário a um dado estado de alma, por outro, os procedimentos de discursivização próprios ao modo peculiar de narrar nos oferecem a oportunidade de melhor compreender em que disposições ele é incitado a ela. Diante disso, interessa-nos, neste momento, examinar a manifestação discursiva de superfície, avaliando a forma de projeção da enunciação no enunciado e a relação, sobretudo persuasiva, entre enunciador e enunciatário, a qual se faz também por meio das figuras e dos temas que caracterizam os discursos. Para tanto, primeiramente nos deteremos nas estratégias utilizadas na narrativa para determinar a organização e a disposição do enunciado construído. Intimamente ligadas à instância do discurso, essas estratégias controlam os modos de acesso à significação, uma vez que as seleções operadas orientam a apreensão do sentido e dos valores.

A história de Campo Geral é narrada em terceira pessoa, caracterizando, portanto, uma debreagem enunciativa que deveria garantir ao discurso o efeito de sentido de distanciamento e objetividade. Todavia, há a quebra de tal efeito à medida que a narrativa vai mostrando sua intimidade e ligação com as personagens por meio do discurso indireto livre.

Entrando na interioridade dos atores, o narrador de Campo Geral opera sobre o modo da subjetividade, da intensidade dos seres e das situações que configuram seu discurso, pondo, em cena, a percepção do protagonista, a sua reflexão e o seu posicionamento sobre as pessoas, os acontecimentos e sobre a realidade circundante, os quais acabam por criar a representação de um mundo próprio. Assim, a instância do narrador (aquele que fala) parece apagar-se e passa a ser ocupada pela figura do observador (aquele que vê) centralizada em Miguilim - enuncia-se um eu sob a forma de um ele. Trata-se do que Fontanille (1989) chama de ponto de vista do ator-participante, marcando uma embreagem completa: actancial, porque estabelece um sujeito da ação que age, manipula, sanciona; espaçotemporal, com a observação feita no lugar e no tempo da narrativa; actorial, por estar subjugada a um ator participante da narrativa; e temática, pois a percepção colocada em cena tem um sentido e um valor em relação ao contexto da história.

Desse modo, em Campo Geral, o narrador delega a palavra a Miguilim, que passa a responder pela perspectiva que orienta a narrativa e pela atividade perceptiva. Nessa posição, ele não apenas assiste aos acontecimentos e os dá a conhecer, mas os percebe, examina e perscruta, temendo-os, suspeitando e se emocionando com eles. Os fatos são apreendidos a partir do íntimo de Miguilim. Sua percepção é uma percepção sensível, que reúne inteligível e sensível no acesso à significação.

O ponto de vista engloba, portanto, o conjunto de procedimentos utilizados pelo enunciador para selecionar os conteúdos de seu discurso e orientar a sua interpretação. Como explica Bertrand (2003, p. 114), "compreende-se que a escolha da perspectiva, tanto quanto as focalizações do enunciador, determinam a ordem dos valores postos em cena no texto".

$\mathrm{O}$ uso do discurso indireto livre, instaurando no enunciado, além da debreagem enunciativa (narrador), uma embreagem actancial enunciva de segundo grau (personagem), 
determina a posição e o modo de presença da instância enunciativa, que ora se aproxima do narrado com toda força, quando o discurso ganha em intensidade, ora, ao contrário, distanciase dele como se nada fizesse a não ser narrar a "verdade" do acontecimento. Essa técnica de aproximação e afastamento da instância de discurso projetada, bem como a delegação da palavra à personagem enriquecem a caracterização dos atores do enunciado e acabam surtindo efeitos de sentido sensíveis sobre o enunciatário, que passa a compartilhar a percepção da realidade instituída a partir de diversos ângulos. Vejamos o trecho que segue:

Os enxadeiros tinham ido cortar varas do mato, uma vara grande de pindaíba, e Pai desenrolou a redezinha de buriti. Mas aí Mãe exclamou que não, que queria o filhinho dela no lençol de alvura. Então embrulharam o Dito na colcha de chita, enfeitaram com alecrins, e amarraram dependurado na vara comprida. Pai pegou numa ponta da vara, seo Braz do Bião segurou na outra, todos os homens foram saindo. Miguilim deu um grito, acordado demais. Vovó Izidra rezava alto, foi o derradeiro homem sair e ela fechou a porta. E sojigou Miguilim debaixo de sua tristeza. (ROSA, 1996, p. 111).

Nesta passagem, o enunciatário vai conhecendo a cena por meio dos olhos de Miguilim, como deixa entrever as marcas da projeção actancial. No entanto, quando a personagem é tomada pela intensidade de seus sentimentos, a narração volta à responsabilidade do narrador - "Miguilim deu um grito, acordado demais. Vovó Izidra rezava alto, foi o derradeiro homem sair e ela fechou a porta. E sojigou Miguilim debaixo de sua tristeza." -, que "tira" o enunciatário do acontecido, instalando-o fora da cena enunciada. É quando, cúmplice dos sentimentos do garoto, o enunciatário se comove, partilhando a dor da personagem.

Como esclarece Fiorin (2008, p. 82), “o que há é, como mostra Bakhtin, uma discordância enunciativa entre as duas vozes. Essa discordância não é tanto de sentido, é de tom". E é explorando esse desacordo que o enunciador vai convocando a afetividade, o pathos, de seu enunciatário.

Toda narrativa é marcada por um discurso bivocal, no qual se misturam dois centros de valores: o do narrador, que põe em cena a perspectiva do mundo adulto; e o da personagem central, Miguilim, que conduz a narração sob sua própria perspectiva, a do universo infantil. Essa composição discursiva faz com que o enunciatário alterne de um universo ideológico a outro, de uma hierarquia enunciante a outra. Assim, ao iniciar o enunciado com uma voz em terceira pessoa, o enunciador põe o leitor a seu lado, ou seja, do lado de fora do enunciado, permitindo-lhe uma visão mais objetiva dos fatos; por outro lado, ao dar voz a Miguilim, coloca o enunciatário dentro do enunciado, conhecendo o mundo e os acontecimentos que cercam a personagem a partir de sua visão pueril, de sua subjetividade, que acabam por sensibilizá-lo afetivamente. Com essa variação de ponto de vista, o enunciador instala dois universos ideológicos, que, axiologizados, levam o enunciatário a refletir sobre os modos de ver o mundo, sobre os modos de ser no mundo.

No que se refere à projeção espaçotemporal, podemos dizer que, em Campo Geral, ela reitera a construção bivocal comentada anteriormente. Logo no início da narrativa, o narrador declara:

UM CERTO MIGUILIM morava com sua mãe, seu pai e seus irmãos, longe, longe daqui, muito depois da Vereda-do-Frango-d'água e de outras veredas sem nome ou pouco conhecidas, em ponto remoto, no Mutum. (ROSA, 1996, p.13 - grifo nosso). 
Afirmando que "Miguilim morava (...) longe daqui", o narrador instaura um aqui-agora para sua enunciação e um lá-então para o conteúdo de seu enunciado, colocandose em uma posição de posterioridade em relação à história narrada. Entretanto, ao dar a palavra à personagem, o enunciador, por meio da embreagem espaçotemporal, faz com que o lá-então do enunciado se transforme no aqui-agora da enunciação, trazendo à superfície do discurso a subjetividade da experiência do acontecimento. Ou seja, não se trata somente daquilo que se conta, mas da "experimentação" dos fatos, do espaço e do tempo em si, uma vez que a neutralização operada pela embreagem presentifica o passado permitindo uma aproximação com o narrado.

A embreagem espaçotemporal resgata o tempo e o espaço do ocorrido e, assim, a personagem se destaca não só pelas ações, como também por suas expectativas e reações emotivas. Confundem-se as barreiras que separam o que é da ordem da narração e o que é da ordem do narrado, carregando o discurso de uma passionalidade que afeta o leitor e o torna parte do enunciado pelo compartilhamento de percepções e sensações. De acordo com Oliveira (1995, p. 235):

A aliança mesmo dos dois actantes, um no texto e o outro fora ou, ao menos, à margem, é que proporciona ao segundo ser levado pelo primeiro à significação e nessa embrear-se a tal ponto na rede de transformações que, como seu participante, sente-a inteiramente. Essa aliança é alvo máximo de uma escritura estética que, antes de tudo o mais, objetiva (re-)acordar o maior número possível de sujeitos através da estetização e da vivência estésica do mundo.

O enunciador explora a alternância do sistema de referência espaço-temporal, construindo valores para, a partir deles, manipular o pathos do enunciatário, levando-o a interpretar o discurso da forma como ele pretende.

Além disso, em Campo geral, os valores que sustentam o discurso - integrantes dos universais semânticos vida e morte, vida versus morte - são apresentados à sensibilidade do sujeito, são dados a serem sentidos sob modos figurativos, provocando no enunciatário estados de alma compatíveis aos estados dos sujeitos do enunciado. Nas palavras de Bertrand (2003, p. 247), "esse processo geral da axiologia que pressupõe a intervenção do sensível pode ser comparado à tese segundo a qual as relações entre estética e ética, e mais precisamente a subordinação da segunda à primeira, seriam firmadas na re-sensibilização dos valores". O acesso aos valores é, então, mediatizado por uma disposição afetiva inscrita na figurativização, sensibilizando o enunciatário e tornando-o propenso a estados passionais.

As figuras são, por excelência, como cita Barros (2001), o lugar do ideológico no discurso. A escolha delas, portanto, não é ingênua, e o sentido veiculado carrega em si uma carga semântica e ideológica muito maior, que se potencializa não no que é contado, mas no modo de contar. Como explicam Fontanille e Zilberberg (2001, p. 313), "o timismo difuso investido na figuratividade, e notadamente nas suas qualidades sensíveis, faz seu trabalho".

$\mathrm{Na}$ narrativa rosiana em questão, a figuratividade empregada pelo sujeito da enunciação ao longo da história - e composta, entre outros elementos, pelos brinquedos, animais, paisagem, chuva e sol, o túmulo de Dito, os óculos, etc. - não só cria um efeito de real na caracterização do ambiente, mas também acaba por fazer parte do interior das personagens. $\mathrm{O}$ enunciador explora os sentidos metafóricos, fazendo-as significar sempre muito mais do que se pode perceber em uma leitura mais ligeira. Assim, as figuras que compõem a passagem referente à morte de Dito, por exemplo, além de caracterizar o tema da 
morte, acrescentam a ele outros efeitos de sentido. No trecho abaixo, Miguilim cisma com a ida de Dito ao ninho da coruja:

O Dito não devia de ter ido de manhãzinha, no nascer do sol, espiar a coruja em casa dela, na subida para a Laje da Ventação. Miguilim não quis ir. [...] O Dito contou que a coruja eram duas, que estavam carregando bosta de vaca para dentro do buraco, e que rodavam as cabeças p'ra espiar pra ele, diziam: "Dito! Dito! Dito!” Miguilim se assustava: “- Dito, você não devia de ter ido! Não vai mais lá não, Dito. (ROSA, 1996, p. 100).

A coruja, como se sabe, é tida pela crença popular como um elemento de mau agouro, ligado à morte. Ao unir a cisma de Miguilim a essa imagem e ao percurso figurativo das duas corujas, "carregando bosta de vaca para dentro do buraco" e olhando para Dito, o enunciador cria em seu enunciado um efeito de tensão e presságio, um sentido em devir, que repercute e ressoa na superfície da narrativa, levando o enunciatário a partilhar a carga passional da personagem. Há uma intersecção entre figurativo e sensível.

A figurativização de Campo Geral se faz, portanto, a partir de dois níveis: o de uma representação figurativa de superfície, que concretiza o discurso e coloca em cena objetos do mundo natural, expondo-os ao leitor como se ela o convidasse a se situar entre eles; e o de um dispositivo figural profundo, regendo uma dimensão mais abstrata do discurso. Ambas remetem a uma ordem interpretativa e hermenêutica, mas o figural é que responde pelo sensível. Desse modo, sentimentos, estados de alma, abrem-se em correspondência com as figuras.

No trecho citado a seguir, dois percursos figurativos se intercalam para a concretização do tema que envolve a passagem sublinhada na análise: um, relativo ao universo infantil, de brincadeiras e fantasias; outro, a um universo de sofrimento e angústia:

A Pinta-Amarela tirou os pintinhos, todos vivos, e no meio as três perdizinhas. A Rosa trouxe as três, em cima de uma peneira, para o Dito conhecer. Mas o Dito mandava Miguilim espiar, no quintal, e depois dizer para ele como era que elas viviam de verdade. A dor-de-cabeça do Dito tinha voltado forte, mas agora Luisaltino tinha trazido as pastilhazinhas, ele engolia, com gole d'água, melhorava. - "Dito, as três perdizinhas são diabinhas! A galinha pensa que elas são filhas dela, mas parece que elas sabem que não são. Todo tempo se assanham de querer correr para o bamburral, fogem do meio dos pintinhos irmãos. Mas a galinha larga os pintos, sai atrás delas, chamando, chamando, cisca para elas comerem os bichinhos da terra..." A febre era mais muita, testa do Dito quente que pelava. - "Miguilim, vou falar uma coisa, para segredo. Nem pr'a mim você não torna a falar." O Dito sentava na cama, mas não podia ficar sentado com as pernas esticadas direito, as pernas só teimavam em ficar dobradas nos joelhos. Tudo endurecia, no corpo dele. - "Miguilim, espera, eu estou com a nuca tesa, não tenho cabeça pra abaixar..." De estar pior, o Dito quase não se queixava. (ROSA, 1996, p. 104-105).

A figurativização constrói, no excerto acima, potencialidades de valores; a galinha e seus pintinhos remetem ao tema da infância, da vida, da brincadeira, daquilo que encanta as crianças, instalando no enunciado um universo pueril e inocente. As descrições do estado de Dito e sua piora, por outro lado, colocam em cena o tema da morte. Mesmo envolvido pela puerilidade e inocência do universo infantil, o enunciatário se depara também 
com a seriedade do mundo adulto, onde fica claro que as coisas não vão bem e que predizem um trágico final. Assim, a adição de um percurso figurativo a outro faz com que não só as figuras se misturem, mas também os valores por elas veiculados. Conteúdos de vida e conteúdos de morte se entrecruzam configurando uma temática passional que acaba por afetar também o enunciatário.

Nessa passagem, assim como acontece em toda a narração referente à morte de Dito, as figuras se apresentam sob uma série de contradições, choques e sobreposições entre os valores de vida e morte. Dito morre justamente no Natal, e as figuras que se relacionam a essa data - o presépio e suas personagens - preparam uma verdadeira contradição entre a espera do nascimento simbólico de uma criança e a morte efetiva de outra. $\mathrm{O}$ enunciatário, então, oscila entre um universo de puerilidade e singeleza a outro, em que se anuncia sofrimento e dor; pressentindo o que virá e colocando-se no lugar de Miguilim, vai se compadecendo.

Os valores que estão na base de construção do discurso de Campo Geral infância/vida vs. maturidade/morte - permeiam, como se pode observar, todo o narrado, incitando a afetividade do enunciatário.

\subsection{Os procedimentos de textualização.}

As considerações feitas até aqui procuraram prender-se, dentro do possível, ao plano de conteúdo do texto examinado, mas a análise prossegue, detendo-se agora às especificidades da manifestação textual, à passagem do plano do conteúdo ao plano da expressão, que é o lugar de acolhimento da textualização. Assim, interessa examinar, neste momento, de que modo o enunciador de Campo Geral recorre ao plano de expressão, à língua, para a composição da dimensão sensível do discurso.

$\mathrm{Na}$ textualização dessa narrativa, a enunciação poética opera apenas uma linguagem, a verbal. Os recursos de pontuação, a organização sintática das frases, o uso de orações condensadas e as construções elípticas, bem como as rimas e aliterações, ocupam papel de destaque dentro desse discurso, ajudando a potencializar o sentido e criando, para o texto escrito, um estilo típico à linguagem oral.

Chamado pelos críticos de "alquimista da palavra", o autor mineiro, como diz Candido (1994, p. 76), "penetra no miolo do idioma, alcançando uma espécie de posiçãochave [...] capaz de conduzir a alta tensão emocional de sua obra". Explorando as possibilidades latentes do sistema da língua, Rosa faz com que cada palavra de seu discurso seja em si mesma um enunciado, como se pode ver no trecho abaixo:

A mãe não se lembrava, não podia repetir as palavras certas, falara na
ocasião qualquer coisa, mas, o que, já não sabia. Ele mesmo, Miguilim,
nunca tinha reparado antes nos cabelos, no narizinho do Dito. Então, ia para
o paiol, e chorava, chorava. Depois, repetia, alto, imitando a voz da mãe,
aquelas frases. Era ele quem precisava de guardá-las, decoradas, ressofridas;
se não, alguma coisa de muito grave e necessária para sempre se perdia.

(ROSA, 1996, p. 113; grifo nosso)

Nessa passagem, Miguilim sofre com medo de perder a lembrança do irmão morto. Com o passar do tempo, a dor e o sofrimento iam diminuindo, e ele via nisso uma forma de esquecimento. Essa ideia, no entanto, não está explicitada no discurso, mas subjaz a ele pela textualização. Tanto as palavras escolhidas como a pontuação, o conjunto linguístico 
como um todo, levam a esse sentido: a repetição do verbo chorar ("e chorava, chorava") traz à tona a intensidade e a duratividade da ação; a pontuação dispensável do ponto de vista gramatical ("Depois, repetia, alto, imitando...") potencializa a atitude descrita e imprime um ritmo mais lento à leitura, atribuindo ênfase prosódica aos vocábulos separados por ela, o que acaba por acrescentar um sentido novo àquele já dado pelo conteúdo; as palavras "decoradas" e "ressofridas" carregam o sentido do que não pode ser esquecido, do sofrimento que precisa ser revivido e, por isso mesmo, são colocadas no texto de modo a enfatizar, intensificando, a passionalidade de seu conteúdo semântico, não apenas para descrever a emoção, mas para torná-la patente.

Operando com a linguagem verbal desse modo, a que os críticos chamam "desvulgarização da língua", o autor convoca a compreensão ativa do enunciatário, que precisa ir além do reconhecimento da forma utilizada, compreendendo-a em um contexto concreto preciso, em uma enunciação particular, responsável por acrescentar emoção ao sentido já dado pelo conteúdo. Assim, segundo Coutinho (1994, p. 16), "constituem uma grande evidência da preocupação constante de Guimarães Rosa com uma total integração em sua obra entre forma e conteúdo" . O crítico explica ainda que:

As longas enumerações, a inversão da ordem normal dos vocábulos, as construções "condensadas" ou elípticas, e as técnicas de pontuação são empregadas, em muitos casos, com o fim de refletirem, de maneira visual ou auditiva, a impressão ou conceito que o autor quer transmitir. (Idem, ibid)

De fato, no discurso de Campo Geral, tais recursos são utilizados de maneira a conferir uma certa cadência, um certo ritmo que se associa ao conteúdo veiculado e combina com ele, aumentando a passionalidade e permitindo ao enunciatário partilhar as emoções e tensões pelas quais passa a personagem. As construções elípticas e a inversão da ordem tradicional dos vocábulos e dos sintagmas na oração forçam o enunciatário a participar mais ativamente da produção da significação, pois ele tem de suprir o que está faltando, tem de organizar os vocábulos para poder dar sentido à narrativa e acompanhar o seu desenvolvimento. Além disso, a articulação insólita e as desconstruções operadas levam o enunciatário a apreender as nuances de sentido contidas em cada palavra. Novos sentidos são acrescentados, intensifica-se a carga emocional, correspondendo a uma analogia íntima entre a língua e a psicologia das personagens.

Dessa forma, os estados passionais definidores de toda a estrutura sintáxica da narrativa são recriados na expressão, convocando o leitor a uma percepção sensível e levandoo a sentir, a experimentar os estados e as sensações da personagem. Rosa trabalha cada vocábulo para que, além do conteúdo semântico, também os sons desvendem, fenomenicamente, as relações íntimas entre o significado e o significante. Ele dá à linguagem verbal escrita acentos de sentido próprios à linguagem oral, revitalizando os recursos da expressão poética, tais como: ritmo, aliterações, cortes e deslocamentos de sintaxe, vocabulário insólito, erudito e arcaico, neologismos, dando a conhecer uma realidade viva.

Forma do conteúdo e forma da expressão fundem-se em um movimento de condensação e expansão do sentido, de modo que uma invade e amplia a substância produzida pela outra, para gerar um sentido unificado.

A colocação do discurso direto na narrativa também é usada de maneira expressiva. Optando, na maioria das vezes, pela não marcação convencional - dois pontos, travessão e fala no parágrafo subsequente - o enunciador mantém um ritmo contínuo ao que

${ }^{1}$ A integração entre forma e conteúdo a que o crítico se refere diz respeito ao quadro teórico da teoria literária Disponível em: http://seer.fclar.unesp.br/casa 
vem sendo narrado; quando opta pela disposição mais comum, usa a pausa que se faz por meio da pontuação também como efeito de sentido de acréscimo ao que é dito, conforme mostra esta passagem:

Pai tinha uma lata d'água, e uma cabaça com rolha de sabuco, mais tinha um coité, pra beber. Mesmo muitos mosquitos, abelhas e avespas inçoavam sem assento, o barulhim deles zunia. Pai não falava.

- Pai, quando o senhor achar que eu posso, eu venho também, ajudar o senhor capinar roça...

Pai não respondia nada. Miguilim tinha medo ter falado bobagem faltando ao respeito.

- Estou comido, regalo do corpo e bondade de Deus. Agora volta p'ra casa, menino, caça jeito no caminho não fazer arte.

Migulim pegava o tabuleirinho vazio, tomava a benção a Pai, vinha voltando. (ROSA, 1996, p. 69/70).

Observe que as pausas impostas pela pontuação e a distribuição do conteúdo em diferentes parágrafos caracterizam a relação de Miguilim com o pai. Entre eles não havia intimidade ou cumplicidade, de modo que o diálogo é esparso e cheio silêncios. Por outro lado, as falas colocadas todas em um mesmo período, apenas destacadas pelo uso de aspas e travessão, recriam a dinamicidade do momento, a simultaneidade e vivacidade da linguagem conversacional entre interlocutores mais próximos, como se pode observar no trecho abaixo:

Miguilim vinha trazer as pipocas, saltantes, contava o que a Rosa tinha gritado, prometia que Papaco-o-Paco já estava começando a soletrar o nome do Dito. O Dito gemia de mais dor, com os olhos fechados. -"Espera um pouco, Miguilim, eu quero escutar o berro dessas vacas..." Que estava berrando era a vaca Acabrita. A vaca Dabradiça. A vaca Atucã. O berro comprido, de chamar o bezerro. - "Miguilim, eu sempre tinha vontade de ser um fazendeiro muito bom, fazenda grande, tudo roça, tudo pastos, cheios de gado..." - "Mas você vai ser, Dito! Vai ter tudo..." O Dito olhava triste, sem desprezo, do jeito que a gente olha triste num espelho. - "Mas depois tudo quanto há cansa, no fim tudo cansa..." Miguilim discorreu que amanhã Vovó Izidra ia pôr o Menino Jesus na manjedoura. Depois, cada dia ela punha os Três Reis mais adiantados um pouco, no caminho da Lapinha, todo dia eles estavam um tanto mais perto - um Rei Branco, outro Rei Branco, o Rei Preto - no Dia de Reis eles todos três chegavam... "- Mas depois tudo cansa, Miguilim, tudo cansa ..." E o Dito dormia sem adormecer, ficava dormindo mesmo gemendo. (ROSA, 1996, p. 106).

Desse modo, ao contrário do que se pode pensar em um primeiro momento, e como já ressaltado por diversos dos críticos que se dedicam ao exame das obras rosianas, a linguagem verbal, em tais narrativas, é usada muito além da sua função utilitária; ela não se coloca como um meio para transmissão do conteúdo, e sim como forma de enfatizar o sentido a ser sentido. Em Campo Geral, a dimensão passional, que caracteriza o discurso, é recriada na textualização, na forma como a linguagem verbal é articulada. $O$ conteúdo semântico de cada palavra, de cada expressão, é potencializado de modo que ele passa a ser vivido, a ser experimentado, criando maior cumplicidade entre o sujeito do enunciado e sujeito da enunciação. 
CASA, Vol.9 n.1, julho de 2011

\section{Considerações finais}

É comum no discurso literário que o sujeito enunciador não se limite a criar o simulacro do chamado "real", colocando em cena aspectos do mundo natural, mas apresente um mundo diferente, convidando o enunciatário a participar, a penetrar na esfera de uma realidade outra. Trata-se, na maioria das vezes, de um enunciado com uma enunciação fundada na função estética da linguagem, que inaugura sobre uma semiótica primária um outro sistema, uma outra forma, transferindo a realidade conhecida para um outro plano axiológico e submetendo-a a uma nova unidade, que a ordena de modo diferenciado, concretizando-a, individualizando-a e arrematando-a, de maneira a levar o homem à reflexão e ao autoconhecimento. Importam a essa enunciação as experiências com o conteúdo e a expressão, sendo que a última passa a ocupar um papel de relevância na composição discursiva.

No caso do enunciador de Campo geral, isso é fato. Ele se apropria, sem dúvida, de um trabalho estético com a língua e da articulação dos mecanismos discursivos para uma construção participativa do universo narrativo, fazendo com que o enunciatário se funda mesmo à personagem Miguilim, colocando-se em seu lugar e compartilhando suas descobertas, suas alegrias e dores. A afetividade de seu discurso se configura, desse modo, no momento mesmo da semiose, da manifestação da significação.

A estranheza das construções do discurso rosiano fere a percepção do leitor, forçando-o a refletir sobre o significado de cada palavra, de cada expressão utilizada, e levando-o a enxergar além do conteúdo ordinário, além do sentido veiculado independentemente do plano da expressão ali articulado. O leitor passa, então, de mero consumidor a participante ativo do processo criador, ao mesmo tempo em que é afetado pela significação ali presente. Torna-se preciso ler e reler o texto com atenção, para que a aproximação com o dito e com o modo de dizer se torne possível. A textualização se coloca, nesse sentido, como uma interface entre a produção e a apreensão do discurso de Campo Geral.

Os conteúdos da percepção e os do enunciado se sobrepõem, interpenetrando-se, aptos para sobrevir concorrencialmente uns aos outros no processo de significação. Ao sentido já dado pelo conteúdo alia-se aquele contido e transmitido pela plasticidade, pela organização e articulação da língua, que potencializa o acontecimento apresentado e a passionalidade que lhe é subjacente. Como bem coloca Fabbri (2002, p. 101), "é próprio do estético reatar o pacto originário do sensível e do sensciente, do qual aflora, diretamente da percepção, o pensamento".

Assim, o pathos na narrativa rosiana é produzido e enfatizado pelo prazer estético de uma obra bem construída. O sentir é convocado, levando o enunciatário a sair de seu mundo para entrar no do enunciado.

\section{Referências bibliográficas}

BERTRAND, D. Caminhos da semiótica literária. Trad. Grupo CASA, sob a coordenação de Ivã Carlos Lopes et al. Bauru, SP: EDUSC, 2003.

CANDIDO, A. O homem dos avessos. In: ROSA, J. G. Ficção completa. v. 1, 1. ed. Rio de Janeiro: Nova Aguilar, 1994. 75-93 p. 
COUTINHO, E. F. Guimarães Rosa: um alquimista da palavra. In: ROSA, J. G. Ficção completa. v. 1. 1. ed. Rio de Janeiro: Nova Aguilar, 1994. 09-23 p.

DISCINI, N. Semiótica: da imanência à transcendência (questões de estilo). In: Alfa, São Paulo, v. 53, n. 2, 2009, p. 595-617. Disponível em:

http://seer.fclar.unesp.br/index.php/alfa/article/viewFile/2133/1751. Acesso em: 25 jan. 2010.

FABBRI, P. Introdução. In: GREIMAS, A. J. Da imperfeição. Trad. Ana Cláudia de Oliveira. São Paulo: Hacker, 2001, p. 95-111.

FIORIN, J. L. As astúcias da enunciação. São Paulo: Ática, 2008.

FONTANILLE, J. Les espaces subjectifs: introduction à la sémiotique de l'observateur. Paris: Hachette; 1989.

FONTANILLE, J. \& ZILBERBERG, C. Tensão e significação. Trad. Ivã Carlos Lopes, Luiz Tatit e Waldir Beividas. São Paulo: Discurso Editorial / Humanitas, 2001.

MANCINI, R. C. Dinamização nos níveis do percurso gerativo: canção e literatura contemporânea. 2005. 191. Tese de Doutorado apresentada à FFLCH - USP.

OLIVEIRA, A. C. A estesia como condição do estético. In: OLIVEIRA, A. C. \& LANDOWISKI, E. (Eds.). Do inteligível ao sensível. Em torno da obra de Algirdas Julien Greimas. São Paulo: EDUC, 1995, p. 227-236.

ROSA, J. G. Campo Geral. In: . Manuelzão e Miguilim. 9. ed. Rio de Janeiro: Nova Fronteira, 1996, p. 11-142.

TATIT, L. Musicando a semiótica: ensaios. São Paulo: Annablume, 1997.

ZILBERBERG, C. Éléments de grammaire tensive. Limogenes: Pulim; 2006. 